\title{
THE OWNERSHIP AND RECOVERY OF TRUST DEPOSITS.*
}

Deposits held in trust by a bank are somewhat allied to specific deposits, and are more completely under the dominion of the true owner than deposits of the ordinary or general character. The importance of preserving or establishing a trust character for them is apparent, especially after the insolvency of the depository. In this article an attempt will be made to re-classify them, and to show in the light of the more recent decisions, the nature of trust deposits, and when they may be recovered without impairing the rights of other creditors.

r. Trust deposits may be divided into three kinds: first, those made by an agent, executor, receiver, trustee, or other official for the use of some individual, office or estate. The trust relation in these deposits is solely between the depositor and his beneficiary. Usually such deposits are general, and in

*ANALYSIS.

r. Kinds of trust deposits.

2. Importance of distinction between them.

3. Trust deposits of second kind classified.

a. Deposit wrongfully confided to a bank.

b. Deposit wrongfully taken or used by a bank.

c. Deposits wrongfully applied by both bank and depositor.

4. Trust fund to be recovered must exist.

5. When created it is presumed to exist.

6. It may exist though mingled with other funds.

7. Fund is not lost through owner's ignorance.

8. Fund is not lost by diversion.

9. Recovery from replenished fund.

ro. Bank cannot divert trust fund to pay depositor's debt.

rr. Nor forbid him from using trust money to pay other debts.

52. Trust money, deposited individually without bank's knowledge, may be used to pay depositor's debt.

13. Trust money whose character is known by solvent bank can always be recovered.

I4. Duty of bank to watch depositor who has diverted trust fund.

I5. Recovery of interest.

I6. Mode of procedure by owners. 
the event of the bank's failure, the owners and beneficiaries, whether wards, public officers, or principals, share like other general creditors. ${ }^{1}$

Thus an attorney who collects money for his client and deposits it in his own name-an ordinary practice-creates simply a debtor and creditor relation between himself and the bank. His trust relation to his client does not pass over to the bank and charge it as trustee for the money. By a proper suit in equity, however, the client can prevent the bank from paying the money to the attorney, and recover it for himself. ${ }^{2}$

The second kind of trust deposit acquires that peculiar quality by reason of the wrongful action of the depositor or bank, or both, whereby it is entitled to preferential consideration over other deposits. "To have that effect," says the Supreme Court of Missouri, "there must have been something in the circumstances of the deposit to constitute it a special, as contradistinguished from a general deposit. If the deposit belonged to the former class, the beneficiary relation might well arise; if to the latter, in the absence of mala fides, it could not do so, for by a general deposit in good faith the title to the fund deposited passed. The bank became the owner. The relation of debtor and creditor, and that of trustee and cestui que trust created." 8 These distinctions, though clearly existing between the different -parties, have not always been as clearly seen by the court."

The third kind of trust deposit is received in those transactions wherein a bank acts as an agent of the depositor, especially in making collections.

2. The three kinds should always be distinguished, because, should the depository fail, the owner of a trust deposit of the first kind shares the same fate as the other general creditors; ${ }^{5}$

I. Fletcher v. Sharpe, 18 Ind. 276; Officer v. Officer, r2o Iowa 389, 393; Ringo v. Fïeld, 6 Ark. 43; Shaw v. Bauman, 34 Ohio St. 25; O'Connor v. Mechanics' Bank, r24 N. Y. 324, 333; Cavin v. Gleason, ro5 N. Y. 256, 262; Paul v. Draper, I58 Mo. I97; MCAfee v. Bland, Ix Ky. L. Rep. 1.

3. Rhinehart v. New Madrid Mfg. Co., 99 Mo. App. 38r.

3. Paul v. Draper, 158 Mo. 197, 200, affg. 73 Mo. App. I97; Officer v. Officer, x20 Iowa $3^{89}$.

4. See New Farmers' Bank v. Cockrell, no6 Ky. 578.

5. "When deposits are received, unless they are special deposits, they belong to the bank as a part of its general funds, and the relation of debtor and creditor arises between the bank and the depositor. This is equally so whether the deposit is of trust moneys, or funds which are impressed with no trust, provided the act of depositing is no misappropriation of the fund." Fletcher v. Sharpe, 108 Ind. 276, 280; O'Connor v. Mechanics' Bank, 124 N. Y. 324, 333. 
while the owner of a trust deposit of the second and third kind obtains a preference over the other creditors. Hence the attempt, whenever a bank fails, on the part of the creditors to be included in the favored circle of preferred depositors.

3. Trust deposits of the second kind may be divided into three classes: (a) those in which a trust is impressed thereon by reason of the wrongful action of the depositor unknown to the bank. The most common example is the deposit by an agent in his own name of his principal's money. (b) Deposits of the second class are those impressed with a trust by reason of the sole wrongful action of the bank, for example, in receiving a deposit when insolvent. (c) In the third class are included deposits thus impressed because both depositor and bank are in the wrong, for example, in knowingly applying a trust deposit belonging to a principal, to pay the individual debts of the depositor to the bank.

a. The deposits within the first sub-division are impressed with a trust character whenever an agent deposits them in his own name without his principal's knowledge and consent. To do this is to subject them to the risk of appropriation for the agent's debts, and if the principal knew that his agent was thus abusing his authority, doubtless would remove him or withdraw the deposits; surely he would insist on their restoration to his own control. The courts therefore have never hesitated to stamp such a deposit with a peculiar character, and to give to the true owner larger rights for its recovery.

The agent may wrong his principal in two ways: First, by putting the deposit in his own name; secondly, by diverting the money afterward to his own use. ${ }^{8}$ The wrongful use of it may be beyond the bank's ken; of this something will be said else. where. 7 But so long as the bank is in possession of the money, its duty to return it, whether solvent or insolvent, is unquestioned.

Presumably a deposit is thus entered by an agent for a wrongful purpose. On the other hand, if this is done with the principal's knowledge and consent, it would belong to the kind

6. A factor, though insolvent, may continue to make deposits for his principal. Interstate Nat. Bank v. Claxton, $80 \mathrm{~S}$. W. (Tex.) 604; but he has no right to pledge, deposit or apply the property of his principal to secure his own debt. Clemmer v. Drovers' Nat. Bank, 157 Ill. 206, 216; First Nat. Bank v. Schween, 127 III. 573.

\section{See $\S 14$.}


of deposit first described, and be governed by the same principles. 8

b. The second class of trust deposits may be subdivided into those that ought not to have been received, and others, that were rightfully received, but wrongfully used. Deposits received after a bank's insolvency fall within the first subdivision. The bank takes advantage of the depositor's ignorance of its real condition and inflicts on him a manifest wrong; he would not have deposited his money there had he known of the bank's real condition.

The deposits falling within the other subdivision are those deposited for a particular purpose, especially the payment of notes, mortgages, checks and other obligations. In these cases the bank is simply the agent of the depositor to execute his will and agreement. Money thus deposited is impressed with a trust and its diversion does not prevent its recovery if it can be ascertained. ${ }^{9}$

c. The third class of trust deposits are those wrongfully received or used with the knowledge of both parties. Such an act is always smitten down by the judicial power. ${ }^{10}$ Yet the temptation of a bank to abuse its position and take the money of a principal within its grasp to pay the debt of his agent has often been too strong to resist. Such action has always been indefensible in law and morals.

4. To recover the trust fund, it must have an actual, as distinguished from a recorded or theoretical, existence. ${ }^{11}$ The

8. Henry $v$. Martin, 88 Wis. 367 . If one deposits trust money in his own name, which is mingled with the beneficiary's consent or knowledge, its identity is lost and its trust character is destroyed by his own act, and after the bank's failure he cannot recover it as a trust fund. Meldrum v. Henderson, 7 Colo. App. 256.

9. MCKee v. Lamon, I59 U. S. 31 \%.

1o. Metcalf v. Williams, 104 U. S. 93; Keidan v. Winegar, 95 Mich. 430; State Bank v. McCabe, 98 N. W. (Mich.) 20; McLain v. Wallace, I03 Ind. 562. See $\$ 16$.

I1. Byrne v. McGrath, 130 Cal. 316; Contitzental Nat. Bank v. Weems, 69 Tex. 489 ; Ellicott v. Kuhl, 60 N. J, Eq. 333; Collins v. Stewart, 58 N. J. Eq. 392; Board v. Wilkinson, Irg Mich. 655; Sherwood v. Central Mich. Sav. Bank, I03 Mich. I09, I15; Peak v. Ellicott, 30 Kan. I56; Kansas State Bank v. First State Bank, 62 Kan. 788; Travellers' Ins. Co. v. Caldwell, 59 Kan. 156; Hubbard v. Alano Mfg. Co., 37 Pac. (Kan.) 625; City of Lincoln v. Morrison, 64 Neb. 822; Cady v. South Omaha Nat. Bank, 46 Neb. 426 and 49 Neb. r25; State v. Bank, 54 Neb. 725; Union Stock Yards Nat. Bank v. Haskell, go N. W. (Neb.) 233i Harrzson v. Smith, 83 Mo. 210; Bircher v. Walther, 163 Mo. 46r; Midland Nat. Bank v. Brightwell, 148 
crediting of a fund without adding an actual corresponding amount creates no right in the beneficiary to recover the sum credited, whether the amount was actually in the bank's possession or not. ${ }^{12}$ The presence of the money credited in the bank is not enough; it must be an addition. ${ }^{18}$ The contrary view has been expressed, ${ }^{14}$ but is not favored.

Thus A bank sent a draft to B bank to be deposited to its credit. B bank owed $\mathrm{C}$ bank which collected the draft and applied, by instructions, the proceeds in reduction of the sender's indebtedness. The B bank was insolvent and ought not to have received the draft, nevertheless $A$ bank failed to collect the amount of B's receiver, because it had never received

Mo. 358; Shute v. Hinman, 34 Or. 578; Wulburn v. Timmons, 55 S. C. 456; Plano Mfg. Co. v. Auld, I4 S. Dak. 512; Cavin v. Gleason, 105 N. Y. 256, 262; People v. City Bank, 96 N. Y. 32; Bergstresser $v$. Lodewick, 37 N. Y. App. Div. 629; Woodhouse v. Crandall, 197 Ill. 104, revsg. 99 Ill. App. 552; Kirby v. Wilson, 98 Ill. 240; see Bayor v. Am. Trust E Sav. Bank, 157 Ill. 62; School Trustees v. Kirwin, 25 Ill. 73; Union Nat. Bark v. Goetz, 138 Ill. I27; Wetherell v. O'Brien, 140 Ill. 146; Twohy Mercantile Co. v. Melbye, 78 Minn. 357; Bishop v. Mahoney, 70 Minn. 238; Robinson v. Woodward, 48 S. W. (Ky.) 1082; New Farmers' Bank v. Cockrell, 106 Ky. 578; Jones $v$. Chesebrough, I05 Iowa 303; District Township v. Farmers' Bank, 88 Iowa 194; Bradley v, Chesebrough, I1I Iowa I26; Quin v. Earle, 95 Fed. 728; Beard v. Independent District, 31 C. C. A. 562; Pennell v. Deffell, 4 De Gex, M. \& G. (Eng.) 372. A depositor who receives a certificate of deposit is not entitled to priority, even though the bank promised to keep it by itself, if it is mingled with other funds. Bayor v. Am. Trust Sav. Bank, 157 Ill. 62, affg. 5 I Ill. App. 180.

12. City of Lincoln v. Morrison, 64 Neb. 822 ; Midland Nat. Bank v. Brightwell, 148 Mo. 358; Beard v. Independent District, 31 C. C. A. 562. Sce $\$ 5$, note 5 for more cases.

13. Kansas State Bank v. First State Bank, 62 Kan. 788; revsg. 9 Kan. App. 839; Burrows v. Johntz, 57 Kan. 778; Travellers' Ins. Co. v. Caldwell, 59 Kan. 156; Beard v. Independent District, 3 I C. C. A. 562; Perth Amboy Gas Light Co. v. Middlesex Co. Bank, 6o N. J. Eq. 84; Jones v. Chesebrough, I05 Iowa 303; District Township v. Farmers' Bank, 88 Iowa 194, I99; Midland Nat. Bank v. Brightwell, 148 Mo. 358. A check given by a depositor on his bank for the payment of a note in its possession does not impress a trust on his deposit when there is no money in the bank to be impressed by reason of its insolvency. Sherwood $v$. Milford State Bank, 94 Mich. 78 .

I4. In Ryan v. Paine, 66 Miss. 678, an individual sent a draft to a bank for collection, which the bank collected by taking the check of the debtor on itself. He had at that time no deposit in the bank, so his check was an overdraft, but he was solvent. The bank having failed before paying the draft, the court held that a trust existed in favor of the creditor for the sum due the bank in discharge of his over-draft. 
the money. Its action raised an implied trust for the recovery of the draft, or its proceeds from the B bank, but as the draft had been paid to another bank, neither the B bank nor its receiver received the money, consequently there was nothing in the possession of that bank to recover. ${ }^{35}$

Another iliustration of a larger series of cases may be mentioned. A bank received from a customer a check on $B$ bank, which was sent to the drawee for payment. Before paying, the $B$ bank failed. A bank then sought to impress a trust on the assets of the $B$ bank for the amount. But the court denied relief on the ground that, to recover the amount, it must show that the B bank had set aside for its payment a fund having a real existence; that in charging the check to the drawer the bank simply reduced its indebtedness to him, and constituted itself a debtor to the holder of the draft for a corresponding amount; and that no fund was accumulated by this operation for paying the draft. 16

5. After the creation of a trust, the presumption is that the bank has the money until the contrary is shown. ${ }^{17}$

6. When, therefore, the trust fund exists, there can be a recovery notwithstanding an admixture with another fund. So long as its presence can be detected in the original or a substituted form, it can be taken therefrom. ${ }^{18}$ This is based on the conception that in taking money out of the general fund, all except the trust deposit will be taken first, leaving this as the

15. City Bank v. Blackmore, 2x C. C. A. 514.

16. Feuple v. Merchants' and Mech. Bank, 78 N. Y. 269; Citizens' Bank v. Greenville, 7I Miss. 27x; Citizens' Nat. Bank v. Dowd, 35 Fed. 340.

17. Independent District v. King, 80 Iowa 497; City of Lincoln v. Morrison, 64 Neb. 822; Sherwood v. Central Mich. Sav. Bank, 103 Mich. Iog.

18. Matter of Holmes, 37 N. Y. App. Div. 15; Englar v. Offutt, 7o Md. 78; Rittg v. Field, I Eng. (Aris.) 43; Fletcher v. Sharpe, x08 Ind. 276; Pearce v. Dill, I49 Ind. 136; Jores v. Chesebrough, I05 Iowa 303; State v. Northern Trust Co., 70 Minn. 393; Shute v. Hinman, 34 Or. 578; Ferchen $v$. Arndt, 26 Or. I2I; MCAfee v. Bland, II Ky. L. Rep. I; Powell v. Morrison, 35 Mo. 244; Eyerman v. Second Nat. Bank, 13 Mo. App. 289; Swartwout v. Mechanics' Bank, 5 Denio (N. Y.) 555; Kansas State Bank v. First St. Batk, 62 Kan. 788; revsg. 9 Kan. App. 839; Frank v. Kurtz, 4 Pa. Super. Ct. 233. "A principal is entitled in all cases, where he can trace his property, whether it be in the hands of his agent, or of his representatives, or of third persons, to reclaim it, and it is immaterial that it may have been converted into money; so only that it is in condition to be distinguished from the other property or assets of the agent." Roca v. Byrne, 145 N. Y. 182 ; Thompson v. Perkins, 3 Mason (U. S.) 232; Van Alen v. American Nat. Bank, 52 
residuum. ${ }^{19}$ Consequently, any portion of the fund that is left, even though less in amount than the trust deposit, is impressed with this character, and can be recovered by the beneficiary. ${ }^{20}$ But, we repeat, the fund cannot be recovered by simply tracing it into the receiver's estate. Its actual existence there in some form must be proved. 21 Many a beneficiary has been unable to recover, not through his failure to prove the existence of a trust, but of a fund that he could rightfully claim as his own. 22

In the search after a perverted trust fund, the principle should not be overlooked, that a depositor who mingles a trust fund with his own personal deposit, thereby raises a lien in

N. Y. I; Importers aud Traders' Nat. Bank v. Peters, I23 N. Y. 272. " It may be," said Gaines, J., in Continental Nat. Bank v. Weems, 69 Tex. 489, "that when the entire mass is paid away the right to claim a trust in any money or property is forever lost. But if throughout all the trustee's dealings with the funds so mingled together, he keeps on hand a sufficient sum to cover the amount of the trust money, we think it capable of demonstration, that the trust should attach to the balance that is found to remain in his hands." "When the right to pursue and reclaim a trust fund exists, the true owner thereof, where the fund is traced to the possession of another and identified, has the right to have it restored to him, not as a debt due and owing to him, but for the reason that it is his property, wrongfully diverted and withheld; and it can make no difference in regard to the right of recovery in such a case, whether the fund has been traced into the possession of a single individual, or into the hands of a firm or association composed of many persons, or into the form of a bank account. It can be recovered so long as it can be identified in some form provided it has not gone into the possession of a bona fide purchaser without notice." Pearce v. Dill, I49 Ind. 136, 143. A deposit checked out by the husband of the depositor without her authority in settlement of illegal transactions (speculations) of which the bank had knowledge can be recovered by her. Pearce v. Dill, I49 Ind. 136,

Ig. State v. Foster, $5 \mathrm{Wy}$. I99; City of Lincoln v. Morrison, $64 \mathrm{Neb}$. 822; Globe Sav. Bank v. National Bank, 64 Neb. 413; Burnham v. Barth, ${ }_{89}$ Wis. 362 ; Importers and Traders' Nat. Bank v. Peters, I23 N. Y. 272, 278; Van Alen v. American Nat. Bank, 52 N. Y. I; Matter of Holmes, 37 N. Y. App. Div. 15; Wetherell v. O'Brien, I40 Ill. 146; Woodhouse v. Crandall, r97 Ill. ro4; Clemmer v. Drovers' Nat. Bank, 157 Ill. 206, revsg. 57 II, App. xo7; Plano Mfg. Co. v. Auld, 14 S. Dak. 512; Knatchbull v. Hallett, L. R. 13 Ch. Div. 696 .

20. Ibid.

2I. Ober v. Cochrat, II8 Ga. 396 , containing an able discussion of the subject.

22. Frelinghuysen v. Nugent, 36 Fed. 229. Many of the syllabi give a wrong impression of the true ground for denying relief to the applicant, the trust existed, but not the fund. 
favor of the beneficiary on the entire fund.23 And this principle applies to a bank as well as an individual. ${ }^{24}$

7. The beneficiary's ignorance of the perversion of his property, and also of its existence, does not prevent action after his discovery. ${ }^{25}$ And he may pursue the fund regardless of any security he may have in his possession. ${ }^{26}$ Nor can a bank, or its representatives, defeat his recovery on the ground of ignorance of the true nature of the fund at the time of receiving it. 27 But there is one indispensable condition of recovery, the fund in some form must actually exist. ${ }^{28}$ Therefore, from a bank that receives a deposit without knowing its real character and uses it, there can be no recovery, for it is no longer the possessor, and has been guilty of no wrong either in receiving or using it. ${ }^{29}$ This not infrequently happens when an agent or public offcer makes a deposit of the principal's money without informing the bank.

8. In no case does a trust fund lose its real character by the agent's or trustee's action in depositing it to his own individual account. ${ }^{30}$ An individual trustee in thus mingling a trust

23. National Bank v. Insurance Co., I04 U. S, 54 .

24. Sherwood v. Central Mich. Sav. Bank, I03 Mich. Iog.

25. Star Cutter Co. v. Smith. 37 lll. App. 212; People v. City Bank, 96 N, Y. 32; Martin v. Funk, 75 N. Y. 134; City of Marquelte v. Wilkinson, Ix9 Mich. 413; Allen v. Russell, $78 \mathrm{Ky}$. I05; Farmers \&. Traders' Bank v. Fidelity \&o Dep. Co. $108 \mathrm{Ky} .384,387$; Dowie v. Humphrey, 9 I Wis. 98.

26. City of Marquette v. Wilkinson, IIg Mich. 413 .

27. School District v. First Nat. Bank, I02 Mass. x74; Lowry v. Polk Co., 5 I Iowa 50; Long v. Emsley, 57 Iowa Ir.

28. Cases under §r2.

29. City of St. Paul v. Seymour, in Minn. 303; In re Seven Corners Bank, 58 Minn. 5; Moore v. Chesebrough, 8I lowa 489.

30. Leon v. Latimer, 67 Mo. App. 138; Harrison v. Smith, 83 Mo. 210; Stoller v. Coates, 88 Mo. 5I4; Goodwin v. American Nat. Bank, 48 Conn. 550; Swift v. Williams, $68 \mathrm{Md}$. 236; Globe Sav. Bank v. National Bank, 64 Neb. 443; Manhattan Bank v. Walker, I30 U. S. 267; National Bank v. Insuratze Co., ro4 U. S. 54; Randolph v. Allen, I9 C. C. A. 353; Gray v. Johrston, L. R. 3 H. L. Cas. I; Keane v. Robarts, 4 Madd. (Eng.) 20. "Executors and trustees must be made to understand that it is their duty to keep the funds of their trust separate from their other funds and business; that they should, upon no consideration, use the trust monies themselves, or permit to be mingled with their own monies or property. In na other way can they save themselves from trouble, litigation and censure. If they neglect this obvious duty, they have no reason to complain if they meet with trouble and expense, and sometimes with heavy loss. The protection of the rights of those who are not in a situation to protect themselves, makes it the 
deposit with his own, does wrong, and the depository, knowing this, should regard his conduct with great suspicion and act accordingly. It has often been said that trustees have a right to deposit funds to their individual account, and it is true that in some cases this is done with the principal's knowledge and for his benefit. ${ }^{81}$ These cases are exceptional and do not infringe the rule.

In like manner the true character of a trust fund is not lost by the agent's or trustee's wrongful retention or use. ${ }^{82}$ Thus, if a check is given to a bank for collection only, and the proceeds are diverted to its own use, and it afterward assigns, the owner's right of reclamation is not affected by the unauthorized act of the collector. He may, however, fail through inability to trace and identify his property.

9. When the general fund has been drawn below the amount of the trust fund and subsequently replenished, two opinions prevail with respect to the beneficiary's right to the new accumulation. One, that he can recover the portion represented by the smallest balance in the bank; $;^{83}$ the other, that he can recover the whole amount if the replenished fund is sufficient, on the ground that the bank has restored this fund. 84

The second position, without modification, is untenable. If the bank were solvent, there is no reason why the beneficiary should not take the replenished fund; if insolvent, and it can be clearly shown that the accumulation was for him, then he can probably hold it unless he would thereby gain an illegal

duty of courts of justice to require fiduciaries to make good all losses which have been occasioned by their neglect." Chancellor Walworth, Case v. Abeel, I Paige, (N.Y.) 393, 402. In People v. City Bank, 99 N.Y. 32, 37, Danforth, J., said: "The checks were impressed with a trust, and no change of them into any other shape could divest it so as to give the bank or its receiver any different or more valid claim in respect to them than the bank had before the conversion." Citing Van Alen v. American Nat. Bark, 52 N. Y. I; Dows v. Kidder, $8_{A}$ N. Y. r2x.

31. State v. Thiomas, 53 Neb. 464.

32. Ibid. ;.Meldrum v. Henderson, 7 Colo. App. 256; First Nat. Bankv. Hummel, $x_{4}$ Colo. 259; Kansas State Bank v. First Nat. Bank, 62 Kan. 788.

33. Cases under $\$ 12$, note 2.

34. See Bradley v. Chesebrough, III Iowa 126; New Farmers' Bank v. Cockrell, 106 Ky. 578. In United Nat. Bark v. Weatherby, 7o N. Y. App. Div. 279, a brokerage firm deposited in their own name money belonging to two companies, Some of it was drawn out, but replaced with other money. These withdrawals and restorations did not operate to extinguish the identity of the moneys originally deposited, and consequently the companies were rightfully entitled to it. 
preference. But generally a new accumulation cannot be taken by him because he has no better right thereto than other creditors. In no case has he a superior equity over another creditor except to his own money. A new accumulation is not his own money, nor a substitute, save under the conditions above mentioned.

10. While the law presumes that in drawing from such a mingled fund the depositor draws out his own individual fund first, ${ }^{85}$ this does not protect or shield a bank that permits him to pervert for his own use the money of his principal. Consequently, a bank that has improperly withdrawn the fund in payment of his indebtedness to the bank itself, ${ }^{36}$ or for any

35. See cases under $\$ 6$, note 2.

36. Union Stock Yards Bank v. Gillespie, I37 U, S. 4rx; National Bank v. Insurance Co., I04 U.S. 54; Farmers \& Traders' Bankv. Fidelity \& Dep. Co., ro8 Ky. 384; Bright v. King, 45 S. W. (Ky.) 508; Cady v. South Omaha Nat. Bank, 46 Neb. 756 and 49 Neb. 125; Rock Springs Nat. Bank v. Luman, 6 Wy. 123; Globe Sav. Bank v. National Bank, 64 Neb. 413; Nehawka Bank v. Ingersoll, 89 N. W. 618; Munnerlyn v. Augusta Sav. Bank, $88 \mathrm{Ga} .33$; Mayer v. Citizens Bank, $86 \mathrm{Mo}$. App. 422, 425; American Trust \&o Banking Co. v. Boone, 102 Ga. 202; Bundy v. Town of Monticello, 84 Ind. II9; Bank v. Clapp, 76 N. C. 482 ; Commercial Bank v. Jones, 18 Tex. 8Ir; McNulta v. West Chicago Park Comrs., 40 C. C. A. I55; Rochester Turnpike Co. v. Paviour, 164 N. Y. 281. See Hale v. Richards, 8o Iowa I64 and lengthy note 52 L. R. A. 790. A bank cannot retain a deposit applied by a factor belonging to his principal to pay his overdrawn account. Interstate Nat. Bank v. Claxton, $80 \mathrm{~S}$. W. (Tex.) 604. A bank that appropriates the deposit of an insurance company, by suffering the president and cashier to check out the company's money to pay their individual indebtedness, must refund it. An.attachment may be granted against the bank for a conversion of the money. Kelsey v. Bank of Mansfield, 85 N. Y. App. Div. 334; Gerard v. McCormick, 130 N. Y. 26I; Rochester R. v. Paviour, I64 N. Y. 281. The public deposit of an officer cannot be applied by him, or the bank, to discharge his private debt. Shepardv. Meridian Nat. Bank, r49 Ind. 532; Skipwith v. Hurt, 94 Tex. 322; Anderson v. Walker, 93 Tex. II9; Love v. Keowne, 58 Tex. 200; Bank v. Investment Co., 74 Tex. 42I; Carroll Co. Bank v. Rhodes, 69 Ark. 43, 48; State v. Hobson, 5 Ohio N, P. 32r. The sureties on an officer's bond who have his shortage are subrogated to the rights of the county or other public body against the bank. Skipwith Case, 94 Tex. 322. A deposit by a county treasurer to the credit of his trust of money previously borrowed from the bank on his individual note is a trust fund that is not subject to his individual check, nor to the lien of the bank for the money borrowed. Custer Co, v. Walker, ro S. Dak, 594. The deposit of a corporation cannot be appropriated by a bank in payment of the private debt of an officer on a check signed by him for the corporation. Kelsey $v$. Bank of Mansfield, 85 N. Y. App. Div. 334; Gerard v. McCormick, 130 N. Y. 26r; Rochester R. v. Paviour, I64, N. Y. 28x; James Reynolds Elevator Co. v. Merchants Nat. Bank, 55 N. Y. App. Div. I; Beher v. N. Y. Nat. Ex. 
other improper purpose, can be compelled to refund to the true owner. ${ }^{37}$

And if by the drawer's mistake the proceeds of a draft are credited by the discounting bank to an agent, instead of his principal, the bank cannot afterward appropriate the money to extinguish the agent's indebtedness to itself. ${ }^{38}$

Ix. While a bank cannot take and retain trust money within the control of a depositor in payment of his private debt to the bank, it cannot forbid him from using it in paying his debts to others by refusing to honor his checks. ${ }^{39}$ Says a western tribuna1: "A banker is not required to protect the rights of third persons, or to initiate any inquiry between him and the customer."40 This is generally true, yet on all occasions it is a dangerous doctrine to maintain, and courts may well hesitate to apply it to a bank having unquestioned knowledge that a

Bank, I6 Abb. N. C. 458; First Nat. Bank v. National Broadway Bank, 156 N. Y. 459, 467, 468; Ferry v. Home Sav. Bank, II4 Mich. 32I; Merchants Nat. Bank, v. Detroit Knitting Works, 68 Mich. 620. See Johnson v. Hersey, 7o Me. 74. A joint deposit for a special purpose cannot be applied by the bank to pay the indebtedness of one of them. Columbia Finance Es Trust Co. v. First Nat. Bank, 25 Ky. L. Rep. 56x. . A received a check payable to his order, indorsed it in blank, and delivered it to $\mathrm{B}$, instructing him to obtain the money, and remit it to C. B indorsed the check in blank presented it to the drawee bank which, after deducting B's indebtedness, paid him the balance. A recovered the sum thus deducted. Percival v. Strathmore, II2 Iowa 747 .

37. First Nat. Bank v. First Nat. Bank, 58 Ohio St. 207; Manhattan Bank v. Walker, I30 U.S. 267. In Butler Co. v. Boatmen's Bank, 143 Mo. 13, the deposit belonged to a county, which was known by the bank, yet it suffered the depositor to check it out and use it for his own purpose. The bank was liable therefor. Said the court: "The bank occupied to the county the relation of trustee and held the money as a trust fund which could only be applied to the payment of the [county obligations.] In such a case the law is well settled that a misapplication of the funds would constitute a breach of the trust and the trustee would become answerable for all losses occasioned thereby."

38. First Nat. Bank v. Gatton, 172 III. 625.

39. Nehawka Bank v. Ingersoll, 89 N. W. (Neb.) 618.

40. Rock Springs Nat. Bank v. Luman, $6 \mathrm{Wy}$. 123, I4I; Duckett v. National Mech. Bank, $86 \mathrm{Md} ; 400,406$. A was the owner of the shares of a company, of which he was the managing director. He had a similar enterprise of his own. After a time he improperly transferred by check sums from the company's account to his individual account. The bank was under no duty "to inquire into the state of the accounts between the parties." Bark of New South Wales v. Goulburn Valley Butter Co., 87 Law Times (N. S.) 88. 
depositor is perverting his trust for his own wrongful individual use. ${ }^{41}$

In a case of unusual interest and importance a trustee had two checks given to him, one was payable to the order of the cashier of a bank "to deposit to the credit of C trustee." The other was payable to the order of the same cashier "for deposit to the credit of $\mathrm{C}$ being the balance of purchase money due him as trustee from D." Both were placed to the credit of the personal account of $\mathrm{C}$, who drew out the money for his own use and lost it. The court held that the bank had knowledge of the nature of the first check and did wrong in crediting it to C's personal account. Although he might, had the deposit been properly made, have drawn out the money as trustee and afterward misapplied it without thereby involving the bank, this was no excuse for the wrong actually committed and it was responsible for the amount. ${ }^{42}$

12. To this rule, that a bank cannot apply trust money to pay the trustee's individual indebtedness to the institution, there is a noteworthy exception. If the bank did not know, so the courts have declared on many occasions, it can be retained. 13

41. In Rock Springs Nat. Bank v. Luman, $6 \mathrm{Wy}$. 123, I42, the court, after declaring that a bank is liable for converting a trust fund to its own use, adds: "otherwise, when the payment is made to a third person at the direction of the trustee, as in that case the bank becomes the mere channel or medium through which the misapplication is made."

42. Duckett v. National Bank, $86 \mathrm{Md}$. 400, 406, citing Munnerlyn v. Augusta Sav. Bank, 88 Ga. 333; State Nat. Bank, v, Reilly, 124 Ill. 464; Chosen Freeholders v. Newark City Nat, Bank, 48 N. J. Eq. 5 I; Walker v. Manhattan Bank, 25 Fed. 255. See this case in U. S. Sup. Ct. Szuift v. Williams, $68 \mathrm{Md}$. 237. In the Duckett case the Maryland Court of Appeals said: "In the absence of notice or knowledge a bank cannot question the right of its customer to withdraw funds, nor refuse to honor his demands by check; and, therefore, even though the deposit be to the customer's credit in trust, the bank is under no obligation to look after the appropriation of the trust funds when withdrawn, or to protect the trust by setting up a jus tertizagainst a demand. But if the bank has notice or knowledge that a breach of trust is being committed by an improper withdrawal of funds, or if it participates in the profits or fruits of the fraud, then it will be undoubtedly liable."

43. Holly v. Missionary Society, 180 U. S. 284; Dike v. Drexel, II N. Y. App. Div. 77,82,83; Meyers v. N. Y. County Nat. Bank, 36 N.Y. App. Div. 482; Justh v. National Bank, 56 N. Y. 478; Stephens v. Board of Education, 79 N. Y. 183; Southwick v. First Nat. Batk, 84 N. Y. 434; Hatch v. Fourth Nat. Bank, ${ }_{47}$ N. Y. 184; Newhall v. Wyatt, 139 N. Y. 452; Hutchinson v. Mankattan Co., 150 N. Y. 250; Goshen Nat. Bank v. State, I4I N. Y. 379; School District v Bank, ro2 Mass. 174; Wood v. Bank, I29 Mass. 358; First Nat. Bäk v. City Nat. Bank, 102 Mo. App. 357; Safe Dep. \& Trust Co. v. 
This rests on the ancient and crumbling doctrine that money has no earmarks. Why should not the bank be required to refund to the rightful owner in all cases wherein its situation would not be worse than it was before receiving payment? No rule is better established than this, that trust funds do not lose their character by reason of depositing them to the individual account of the depositor. ${ }^{44}$ If, therefore, they still possess this character, why should they not be recovered provided they can still be traced, regardless of their possessor?

This exception from the ordinary rule that applies to every other kind of property, is so illogical that the courts are manifesting a healthy impatience to overthrow it. Accordingly, in the more recent decisions, as we shall see hereafter, 45 the courts have required the banks to account for the money they have thus sought to apply to pay their indebtedness, belonging to their depositors.

In Missouri the courts hold that the addition of the word agent, administrator, trustee and the like, to a person's account is no notice whatever to the bank that the deposit belongs to another. ${ }^{46}$ The additional words are regarded merely as

Diamond Nat. Bank, r94 Pa. 334; Smith v. Des Moines Nat. Bank, ro Iowa 620, reviewing many cases; First Nat. Bank v. Valley State Bank, 60 Kan. 621. A bank that appropriates money collected by a depositor as agent for another without any knowledge of its ownership, to pay his debt to the bank, cannot be recovered therefrom by the principal. London \&o River Platte Bank v. Hanover Nat. Bank, 36 N. Y. App. Div. 487. An agent collected rents of property held by two persons in common and deposited the money to their credit by himself as agent and afterward drew the money out on a check drawn and signed in their names by himself. The bank not knowing the ownership of the fund beyond the record of the deposit, was protected in its action. Carr v. Fidelity Bank, r26 N. C. 186.

44. This is essentially the Michigan view. Burtnett v. First Nat. Bank, 38 Mich. 630. The United States cannot hold, against the claim of an innocent beneficiary, a trust fund that has gone into the treasury through the fraud of its agent. Uuited States $\nu$. State Bank, 96 U. S. 30.

45. Ibid.

46. Sparrow v. State Ex. Bank, 77 S. W. (Ct. of App. Kan. City) 168; Eyerman v. Second Nat, Bank, 84 Mo. 408, affg. I3 Mo. App. 289; Mayer v. Columbia Sav. Bank, 86 Mo. App. 108. A person who deposits money to his credit as "trustee" is notice to the bank that it is trust money. Buhndy v. $B a n k, 84$ Ind. IIg. An agent who asks for a certificate of deposit in his own name of money belonging to his principal is enough to put the bank on inquiry, especially if the president of the bank knew he was irregular and unworthy of confidence. Farmers Loan \&o Trust Co. v. Fidelity Trust Co., 86 Fed. 54r. A bank that discounts a draft drawn by a customer payable to the order of an agent and permits him to credit the amount to his individual 
descriptive of the signer in harmony with the ancient rule that applied to them when used by the makers of notes and checks. Consequentiy, as a deposit thus made is that of the individual who made it, the deposit can be applied to the payment of his individual debt. The application of course is proper, if the deposit can be thus properly regarded. This is contrary to the rule prevailing perhaps in every other state; it should be amended, for it is often in glaring violation of the truth, and sanctions a vicious and dangerous practice. The least that a bank should be permitted to presume in such cases is that the deposit does not belong to the depositor; and if, in truth, it does, that he should furnish clear evidence of the fact.

A bank may rightfully assume, unless possessing contrary knowledge, that the money deposited belongs to the depositor; and consequently that he had a right to draw it out. Therefore, if his successor in office should sue to recover the fund, claiming it was public or trust money, the burden of proof would be on him to establish its trust character. ${ }^{47}$

r3. Whether the courts will continue to apply this principle so generally for the protection of banks that receive deposits regardless of their ownership, it is certain that a trust deposit received by a solvent bank knowing its true character can be recovered. Nor is its recovery conditioned in any way on its existence. Thus a bank which credits the account of a depositor with a forged check can follow the money into the possession of any one who received it with knowledge of the fraud. 48

14. How far a bank should go in watching a depositor who is manipulating a trust fund, seemingly for his own benefit, is

account, and draw against it, in the face of express instructions from the principal to cash only drafts and checks sent by himself is liable for the wrongful diversion of the principal's money. Heinz v. Fourth Nat. Bank, $48 \mathrm{~S}$. W. (Tenn.) 133. An executor who abuses his trust and diverts the fund in his possession for his own purpose does a great wrong; and a broker or other person who receives the money, knowing its true character, or under suspicious circumstances that ought to have led to inquiry before receiving it, is equally guilty and can be compelled to refund. Marshall v. de Cordova, 26 N. Y. App, Div. 615 .

47. Woodbridge v. First Nat. Bank, 45 N. Y. App. Div. 166.

48. Fidelity Trust Co. v. Baker, 60 N. J. Eq. I7o. A having forged the indorsement of a check deposited it with $A$ bank and was credited with the amount. He drew out $\$ 2,400$ by check which he sent to $B$. bank and had credited to an account from which he had wrongfully drawn, without the knowledge of the bank or the depositor, this amount. A bank attempted to recover the $\$ 2,400$ from the other bank, but did not succeed. Nassau Bank ข. National Bank, I55 N. Y. 456 . 
an important question, yet difficult to answer. That it cannot suffer with indifference a trust fund to be diverted and lost, has been often declared. In one of the later cases the duty is thus expressed: "No bank is made to exercise supervisory functions with its depositors. If knowledge comes to the bank that any agent, who is allowed to check upon the funds of his principal on deposit with it, is about to commit a breach of trust in draw. ing checks upon the fund in the bank, of course in such an event it would be the duty of the bank to protect the rights of the principal; but, to acquire this knowledge, such a bank will not be required to exert itself beyond the channels of its business." 49 The judicial expression is quite varied. and if the particular case under investigation requires the application of a severer rule, the views of the court are more strongly colored. When justice evidently requires more leniency, then the rule finally adopted is less severe. The duty of the bank therefore in such cases can never be clearly defined, and must depend to a considerable extent on the circumstances.

Thus no recovery can be had of a bank that lends money to an executor on the pledge of the securities of the estate, though the money is drawn out on a check made payable to his own order, and the money is appropriated to his own use. 50 Nevertheless, if the money is for some one else, would not the practice be far better to require the trustee to give the creditor a

49. Popè, J., Merchants' \& Planters' Nat. Bank v. Clifton Mfg. Co., 56 S. C. 320,338 . See Knobelock v. German Sav. Bank, 43 S. C. 233. "A depositor although holding the money in a fiduciary capacity, may draw it out of the bank ad libitum. The bank is bound to honor his checks, and incurs no liability in so doing so long as it does not participate in any malapplication of funds or breach of trust. The mere payment of the money to, or upon the checks of, the depositor, does not constitute a participation in an actual or intended misapplication by the fiduciary, although his conduct or course of dealing may bring to the notice of the bank circumstances that would enable it to know that he was violating his trust. Such circumstances do not impose upon the bank the duty, or give it the right to institute an inquiry into the conduct of its customer, in order to protect those for whom the customer may hold the fund, but between whom and the bank there is no privity." Interstate Nat. Bank v. Claxton, $80 \mathrm{~S}$. W. (Tex.) 604. In three other important cases the same views have been expressed. Munnerlyn v. Augusta Sav. Bank, 88 Ga. 333, 336; Eyrich v. Capitol State Bank, 67 Miss. 60, 72; Gray $v$ Johnston, L. R. 3 H. L. Cas. p. 14. A bank is responsible for the amount of a note payable to two trustees and indorsed by one for the other without his authority and deposited to his individual account and used. Barroll v, Forman, $88 \mathrm{Md}$. 188 , 2or.

50. Lyman v. National Bank, r81 Mass. 437. 
check; and, if the money is for the trustee himself, to require the bank to satisfy itself of the propriety of the payment before honoring his check? In like manner, ought not a receiving teller, who receives a check from a trustee made payable to him officially and endorsed by him for deposit on his own personal account, to make inquiry concerning the transfer? ${ }^{51}$ In some states this is a wrong; it ought to be thus held everywhere.

Unquestionably a bank is not required to follow the use of a fund withdrawn by an agent or other trustee on adequate authority. . Thus an agent had authority to "endorse and sign checks and deposit money, and make drafts for the use of the company," of which the drawee bank had knowledge. He drew out money "pay to the order of cash," and retained the money. In an action against the bank, the court said: "The authority to sign checks for the use of the company imposed no affirmative duty on the bank to inquire into the purpose of the check, or to the use to which the money was to be put. 52 In another case a partner checked out partnership money in the partnership name and applied it to his individual use, yet the bank was declared to be not liable to the other members unless there was on its part a fraudulent purpose, or actual knowledge of the checking partner's fraudulent design. ${ }^{53}$

15. When trust money has been invested, the beneficiary - can claim the profit on the investment. ${ }^{54}$ And the same rule applies to a bank that has improperiy appropriated trust money to pay the trustee's individual debt to itself. ${ }^{55}$

r6. The true owner cain demand payment, and if the bank rafuses, can recover by legal process, as for money had and received. To maintain the action privity of contract with respect to the money need not be shown, but only that in equity

51. Duckett v. National Mech. Bank, 86 Md. 400; American Bonding Co. v. National Mech. Bank, 97 Md. 598; Bundy v. Monticello Co., 84 Ind. IIg; American Ex. Nat. Bank v. Loretta Mining Co., I65 I11. I03. In Safe Dep. \&o Trust Co. v. Diamond Nat. Bank, I94 Pa. 334, the court thought otherwise.

52. Warren Scharf Asphalt Pav. Co. v. Commercial Nat. Bank, 38 C. C. A. Io8. See Nehazuka Bank v. Ingersoll, 89 N. W. (Neb.) 618.

53. Eyrich v. Capitol State Bank, 67 Miss. 60.

54. Ciity of Lizicolin v. MTorrason, 64 Neb. 822; Farmers \&o Traders' Banl v. Kimball Milling Co., I S. Dak. 388 ; Brown v. Rickets, 4 Johns. Cl. (N. Y.) 303; Frank's Appeal, 50 Pa. тgo; Butler v. Ficks, xI Sm. \& M. (IIiss.) 78 .

55. Anerican Trust \& Bkg. Co. v. Boone, I02 Va. 202. At least from the date of the action. Marshall v. de Cordova, 26 N. Y. App. Div. 6r5. 
and good conscience the money belongs to the claimant. 56 If the bank is insolvent, then he may fail to recover, not by reason of any flaw in his ownership, but through failure to satisfy the law of the existence of the fund belonging to him. 57

Of course, when the beneficiary cannot recover the trust fund, he can prove his claim as a general creditor. ${ }^{58}$

Albert S. Bolles.

56. Deal v. Mississippi Co. Bank, 79 Mo. App. 262.

57. Farmers \& Traders' Bank v. Fidelity \& Dep. Co., $108 \mathrm{Ky} \cdot{ }^{84}$

58. Dowie v. Humphrey, gI Wis، 98. 